\title{
Project Work in CLIL: A Bibliographical Review
}

\section{El trabajo de proyectos en CLIL: una revisión bibliográfica}

\author{
Ricardo CASAN-PITARCH \\ Universidad Católica San Antonio de Murcia, Murcia, Spain \\ rcasan@ucam.edu
}

\begin{abstract}
Learning foreign languages has become necessary in present society, yet most government policies to promote multilingualism seem to have been insufficient. In fact, the European Commission reports that only $35 \%$ of Europeans regularly use foreign languages in their daily lives. As a result, there is a reat need for new language teaching approaches that improve the current educational system. The CLIL approach has been considered an alternative to other more traditional methods, since it involves the integration of language and content. Additionally, project work can be used in support of CLIL approaches in order to increase interaction among participants and promote learning autonomy, making this a desirable part of CLIL programs. To examine the issues surrounding project work in CLIL more closely, this paper provides bibliographical review that analyses the application of project work in CLIL and identifies its main features and possible benefits.
\end{abstract}

Keywords: CLIL; project work; bilingualism; language teaching; education.

\section{Resumen}

El aprendizaje de lenguas extranjeras se ha convertido en una necesidad en la sociedad actual, aunque la mayoría de las políticas gubernamentales para promover el multilingüismo parecen haber sido insuficientes. De hecho, la Comisión Europea señala que solo el $35 \%$ de los europeos utiliza regularmente lenguas extranjeras en su vida cotidiana. Como resultado, existe una necesidad real de nuevos enfoques de enseñanza de idiomas que mejoren el sistema educativo actual. El enfoque AICLE se ha considerado una alternativa a otros métodos más tradicionales, ya que implica la integración de lenguaje y contenido. Además, el trabajo de proyectos se puede utilizar en apoyo a AICLE con el fin de aumentar la interacción entre los participantes y promover la autonomía en el aprendizaje, haciendo de este un método atractivo en los programas AICLE. Para examinar las cuestiones relacionadas con el trabajo de proyectos en AICLE más de cerca, este trabajo proporciona revisión bibliográfica que analiza la aplicación del trabajo de proyectos en AICLE e identifica sus principales características y posibles beneficios.

Palabras clave: AICLE; trabajo del proyecto; bilingüismo; enseñanza de idiomas; educación. 


\section{INTRODUCTION}

Languages have been long been a defining element in the human world, and their diversity has been crucial in the development of mankind, leading up to the present society. In this sense, languages have enabled people to communicate in an effective and efficient way (Hall, 1980; Peirce, 1960-1966; Saussure, 1922; Wren-Lewis, 1983). It is a fact that society and language are in continuous evolution. Chamot and O'Malley (1994) explained that society and language can change through the processes of exploring, conveying information, comparing, classifying, analyzing, justifying, solving problems, synthesizing, or evaluating. As result, these linguistic functions involve an indispensable need for individuals to communicate with others, followed by specific aims and interests.

In the current panorama, globalization seems to contribute to an increased demand for multilingual education (Kramsch, 2014). In fact, the European Union encourages their citizens to become multilingual, with the long-term objective that every citizen should have practical skills in at least two languages in addition to their mother tongues. According to the European Commission (2012), 88\% of Europeans consider that knowing other languages in addition to their mother tongue is very useful, while 67\% of Europeans considered English as the most useful language for communication in international contexts. However, in the same report, the European Commission also noted that only $35 \%$ of Europeans use foreign languages to watch films and television, to listen to the radio, to read in the internet, or to communicate with friends. In addition, only $27 \%$ of Europeans signalled that they used foreign languages at work. These results show that not all Europeans can speak foreign languages; and consequently the European Union has been urged to design new educational plans to fulfil their linguistic objectives of recent decades.

Within this panorama, in which the use of English is a social need but at the same time this aim is achieved only by a minority, governments are concerned about the need to change and introduce 
new educational approaches. The content and language integrated learning (CLIL) approach has been welcomed with approval in many countries due to reports of positive results in Canada, Finland, Germany, Norway, Sweden, and the UK (Cano, 2014; though see also Sylvén, 2013). Thus, it would seem that bilingual education is not only acclaimed by a few but also necessary for most people in response to present social demands.

The main objective of this literature review is to discuss on how to deal with project work in CLIL. Bilingualism offers new ways of language teaching which provide multiple and diverse foreign language practices, whereas project work offers the opportunity to fulfil CLIL objectives and principles through significant cooperative work. The relevance of project work in CLIL is emphasized due to the integrative nature of its approach to teaching, in which all students can access the content while they are simultaneously interacting (active participation) and learning (content, language and learning strategies). In order to achieve the main objective of this study, it is necessary to consider how CLIL and project work can be integrated in order to be effective in the bilingual classroom.

\section{THE APPROACH: CONTENT AND LANGUAGE INTEGRATED LEARNING (CLIL)}

\section{Theoretical principles of CLIL}

According to Coyle, Hood, and Marsh (2010), the CLIL approach is a dual-focused educational approach that uses an additional language in the learning and teaching of content and language. Although the emphasis is sometimes given to one or the other, they are united in an innovative way. Similarly, Pérez Vidal (2013) describes this approach as a variant of bilingual education characterized by the relationship between content (no-language subject matter) and language (nonnative language). Thus, CLIL uses the target language to teach students both content and language. The aim of this approach is not only 
to "teach in a foreign language but also with and through a foreign language" (Eurydice, 2006).

In recent years, a considerable amount of literature has been published on CLIL's theoretical principles (Banegas, 2013; Coyle et al., 2010; Pérez Vidal, 2013; Pérez Cañado, 2012). To start with, CLIL is based on constructivism, a theory of knowledge that argues that people generate knowledge and meaning from their experiences. People create their own rules and mental models which are used to make sense of their experience. Therefore, learning is simply the process of adjusting our mental models to accommodate new experiences (Towomey, 2005). In methodologies based on constructivism, teachers should facilitate and promote discussion, while students should be guided by teachers in order develop their own conclusions on the subject of study. In this case, the CLIL instructor is not merely a subject teacher but also a facilitator and good practitioner in the classroom (Bautrsfeld, 1995).

Concerning the basic principles of language teaching, CLIL fosters communicative situations in the classroom, in which students are not conscious of the language acquisition process. Krashen (1985) made a distinction between acquisition and learning. The former is a subconscious process which refers to the act of gaining communicative competence in languages in a natural way through real situations and interaction, whereas the latter is a conscious process that is related to the students' experiences in school. Thus, CLIL situations focus on a subconscious acquisition of the language while students are conscious of the content learning.

These ideas about acquisition and learning are related to the necessity of providing students with comprehensible input. This must be based on students' needs and interests, as well as accessible, given their cognitive level, just as explained in Krashen's input hypothesis (1985). However, as Swain (1985) criticized, students involved in acquisition and learning processes need a greater exposure to the target language, in terms of both input and output. This exposure to the 
language is essential in CLIL contexts, and Swain's output hypothesis provides three fundamental functions:

- Noticing: Students encounter gaps between what they are able to say and what they want to say, so students notice gaps in their own linguistic knowledge.

- Hypothesis testing: When learners produce utterances, they usually receive feedback from an interlocutor. This feedback is useful to test their utterances.

- Metalinguistic awareness: Students are able to reflect about how the language they learn work.

As result, this approach offers various opportunities for interaction through negotiation of meaning, whose communication strategies facilitate learners' $\mathrm{L} 2$ development and the chance to receive further input and feedback (Long, 1983, 1996). Therefore, the use of interactions in the classroom helps students improve their language proficiency. These interactions can be established among students as well as between learners and teachers when the learning process is scaffolded by the teacher or by the most capable students. Vygotsky (1978) refers to the Zone of Proximal Development (ZPD) to describe the learning process when it becomes challenging but still achievable. In other words, this refers to the distance between the actual developmental level (what I can do) and the level of potential development under teacher or students' guidance (what I can do with help).

Within this social constructivist approach developed in CLIL contexts, the teacher's role is one of facilitator, to ensure there is appropriate balance between cognitive challenge and support. At the same time, social-constructivist approaches to learning emphasize "the centrality of student experience and the importance of encouraging active student learning rather than a passive reception of knowledge" (Cummins, 2005, p. 108). This fact promotes social interaction between students-students and teachers-students which requires an active participation of students both individually and cooperatively in teams (Prince, 2004). In addition to this, Mehisto, Marsh, and Frigols 
(2008) also suggest that this focus on students' teaching-learning centred approach increases motivation, being fun and challenging. High levels of motivation and implication in the learning process involve learners in a rich learning environment in which students construct new knowledge by establishing links between what they already know and what they have to learn (Ausubel, 1978).

Developing significant learning in the classroom is essential. In order to achieve this purpose, students need to encourage their learning-teaching process with the appropriate assistance. Bruner (1978) coined the term scaffolding to refer to the assistance given by the teacher (or more knowledgeable peer) in offering comprehensible input and helping learners get into the ZPD. In other words, the good CLIL teacher must facilitate the students' learning by using contexts that are familiar to them. Scaffolding includes everything teachers do when they predict difficulties that the whole class or any individual will encounter in a given task. Some examples of scaffolding refer to the activation of background knowledge at the beginning of the lesson (warm-ups) or a brief review of key vocabulary at the end of it (follow-up activities). In this context, Cummins' model of bilingual pedagogy (2000, p. 71) states that "language and content will be acquired most successfully when students are challenged cognitively but provided with the contextual and linguistic supports or scaffolds required for successful task completion". Thus, five criteria are considered for effective scaffolding which is established by the following items (Applebee, 1986):

- Student ownership of the learning event: The instructional task must allow students to make their own contribution to the activity as it evolves.

- Appropriateness of the instructional task: The tasks should build upon the knowledge and skills the student already possesses but should be sufficiently difficult enough to allow new learning to occur. 
- Astructured learning environment: This provides a natural sequence of thought and language; thus, the student should get valuable information on useful strategies and approaches to the task.

- Shared responsibility: Tasks are solved jointly in the course of instructional interaction, so the role of the teacher is more collaborative than evaluative.

- Transfer of control: As students internalize new procedures and routines, they should take a greater responsibility for controlling the progress of the task such that the amount of interaction may actually increase as the student becomes more competent.

Another relevant issue in CLIL is the need to focus on both form and meaning. According to Llinares, Morton, and Whittaker (2012), the CLIL approach defends the importance of focusing on communication to achieve academic success, but a focus on form is also required. This approach to language (form and meaning) is influenced by specific features of the program and the role of the second language. In this sense, some CLIL programs incorporate both specific language objectives as well as content ones. However, some authors also claim that content teachers in CLIL programs are responsible for coordination as they use a second or foreign language in order to obtain content objectives. Thus, language is the vehicle to obtain these: "CLIL classes are influenced by a move towards a focus on form, which represents the most significant contribution from research in the field of second language acquisition to the field of Language Teaching" (Muñoz,2007, p. 23). As can be observed, the use of complete integration between form and meaning is a given characteristic of CLIL classes; teachers select content aims related to the subject, but they ensure that the demands of language are appropriate in order to get the expected results in both areas: content and language.

\section{THEORETICAL ISSUES IN THE APPLICATION OF CLIL}

In order to ensure the appropriate application of CLIL, educators need to consider certain theoretical issues that offer the appropriate features 
to obtain a close relation between the of CLIL and its success. The main consideration for implementing CLIL in the classroom and the design of suitable materials for this is Coyle's (2005, p. 3) 4Cs framework, a planning tool that combines communication, content, cognition, and culture as shown in Figure 1.

\section{FIGURE 1. The 4Cs framework for CLIL}

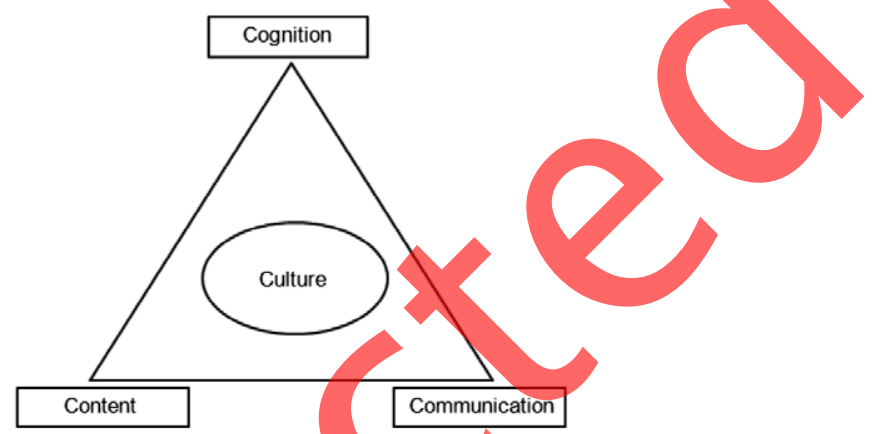

Source: Adapted from Coyle, Hood \& Marsh (2010).

The first item that needs to be considered is content; this refers to the subject or the project theme which provides the basis for learning. Content learning occurs through the acquisition of knowledge and the necessary development of particular skills. Firstly, teachers must establish teaching aims (what the specific teacher intents to do with specific pupils) and learning outcomes (what the teacher wants students to be able to do at the end of the didactic unit). Coyle (2005) showed that content determines learning progression. For example, if students only use present tense in their science interaction, the fluency will be limited. Thus, if the content provided in the lesson requires the use of past tenses, students should have access to these specific language forms. In this sense, the key in this approach is the continuous accessibility to new forms of language during their learning process.

Once the content has been established, teachers must plan for communication, which refers to the language used as a conduit for communication and learning (Coyle, 2005). It should also be emphasized that communication goes beyond a language's grammar system and 
aims at interaction in real life situations. The principle of learning to use a language and using language to learn is applicable within this context. Thus, language needs to be clear and comprehensible for the student. For this aim, the language triptych can be used analyze the language needs in CLIL settings. The language triptych (Figure 2) integrates content learning cognitively with language learning and use: "Using the language to learn is as important as learning to use language" (Coyle et al., 2010, p. 35). As shown in Figure 2, the balance between language and content involves three kinds of language, which are extracted from the language triptych: language of learning is the language needed for learners in order to access concepts and skills related to the topic; language for learning is the language needed to operate in foreign language classrooms (work in groups, asking questions, debating); and language through learning is unplanned emerging language which appears in classrooms due to the high level of talk, interaction, and dialogic activity.

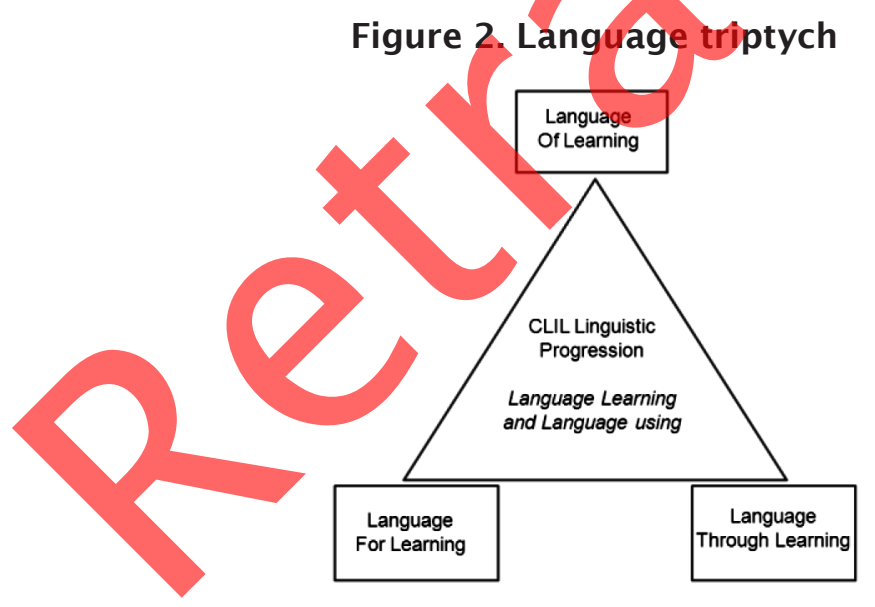

Source: Adapted from Coyle, Hood \& Marsh (2010, p. 36).

The next item on the list of the 4Css is cognition. Learners in CLIL are challenged to develop thinking skills that link concept formation (abstract and concrete), understanding, and language use. Cognition encourages students to think and construct their own interpretation of content. Furthermore, "content needs to be cognitively engaging 
to students, with tasks which promote problem solving and higherorder thinking processes" (Banegas, 2013, p. 86). When planning for cognition, teachers determine the thinking skills that must be learned. These resources can be based on the taxonomy introduced by Bloom (1956), which help teachers define cognition demands according to linguistic and cognitive abilities. This taxonomy of learning objectives has become a key tool in the learning process in CLIL, and it is divided into two categories: Lower Order Thinking Skills (LOTS) and Higher Order Thinking Skills (HOTS). LOTS (knowledge, comprehension, application) are skills used to develop basic understanding and to prepare students to access higher thinking skills, whereas HOTS (evaluation, synthesis, analysis) are skills used to interpret and manipulate abstract information and apply knowledge in a practical way. These skills can be ranked in order, from LOTS to HOTS; in other words, from easy to difficult. More recently, Bloom's original taxonomy was revised by Anderson and Krathwohl (2001); the key in this new model is the use of verbs (actions) rather than nouns (processes) in the thinking skills categories. So, LOTS are remembering, understanding, and applying; while HOTS are analyzing, evaluating, and creating. Table 1 shows both Bloom's (1956) and Anderson and Krathwohl's (2001) versions of the taxonomies.

The last item on the 4Cs' list is culture. The study of a foreign language is vital to foster linguistic and cultural awareness (Coyle, 2007; Pérez-Gracia, 2014). Culture offers a wide interpretation of citizenship and promotes tolerance and a feeling of understanding among subjects from different cultural and geographical backgrounds (Byrd, 2014). For this reason, educators should consider approaches to implementing work with culture as an essential element in the development of the CLIL approach in the classroom. Coyle (2009) affirms that there is a relation between culture and language learning. In this sense, culture contributes to carrying out the dual focus (on content and language learning) of CLIL. In addition, the interaction with diverse cultural contexts in order to use the foreign language 


\section{Table 1. Bloom's (1956) and Anderson and Krathwohl's (2001) taxonomies of thinking skills.}

\begin{tabular}{|c|c|c|}
\hline$\uparrow$ & Higher Order Skills & Higher Order Skills \\
\hline & Evaluation & Creating \\
\hline & Synthesis & Evaluating \\
\hline & Analysis & Analyzing \\
\hline & Application & Applying \\
\hline & Comprehension & Understanding \\
\hline & Knowledge & Remembering \\
\hline & Lower Order Skills & Lower Order Skills \\
\hline
\end{tabular}

Note: Adapted from Taxonomy of Educational Objectives: The Classification of Educational Goals, Handbook I: Cognitive Domain, by B. S Bloom, M. D. Engelhart, E. J. Furst, W. H. Hill, D. R. Krathwohl, 1956, New York, NY: Longmans, Green; and A Taxonomy for Learning, Teaching, and Assessing: A Revision of Bloom's Taxonomy of Educational Objectives (pp. 67-68), by L. W. Anderson, D. R. Krathwohl, P. W. Airasian, K. A.Cruikshank, R. E. Mayer, P. Pintrich, M. Wittrock, 2001, Boston, MA. Allyn \& Bacon.

as a means of communication provides significant opportunities for the development of cultural awareness. In other words, cultural awareness grows through contact and interaction with different people and new settings in which students can use the target language to extract information and practice their speaking. Consequently, culture is not only considered an important item in CLIL but is also vital in the development of awareness of self and otherness (Cano, 2014). This awareness plays a crucial role in the learning-teaching of a subject through a foreign language because students need to be conscious of how theylearn and how the context can help them to learn (Coyle, 2009).

As has been shown, the aim of the 4Cs framework is to help teachers make good designs and carry out an appropriate implementations of the CLIL approach. It pursues the integration of content and language, in which sense the 4Cs framework offers a way to provide an integrated alliance of these two elements. However, this process of integration also requires a clear design of tasks. Teachers need to achieve a balance between cognition and language in their activities and materials. In this sense, Cummins' (1984) Matrix models how the sequence of activities can be planned, from lower order thinking and lower linguistic demands 
to higher order thinking and higher linguistic demands. Coyle et al. (2010) adapted Cummins' Matrix to CLIL settings (Figure 3).

Figure 3. CLIL Matrix

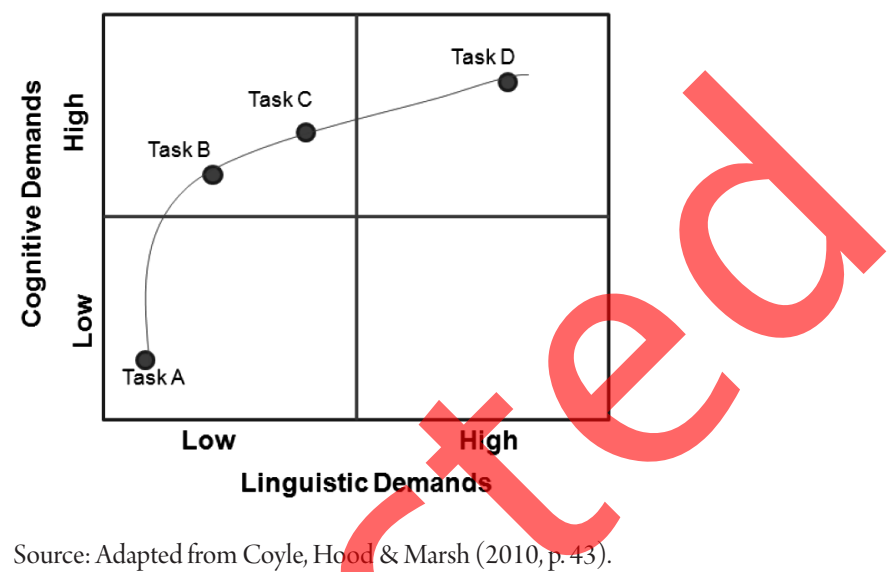

The model shown in Figure 3 suggests that the level of difficulty can be graded according to the cognitive and linguistic demands. This model suggests four different positions. Task $A$ refers to activities that focus on instilling confidence in students with familiar and usual work as starting point. Tasks in position $B$ use recycled language, but in this case they require added cognitive demands on students by introducing abstract concepts, while also using visuals to scaffold the new knowledge. In the following position, Task $C$ continues developing new knowledge, but the language demands are more complex. Finally, Task D incorporates new language and new content, and students engaged in cooperative group-work through technological and/or teacher support.

These theoretical issues in CLIL suggest practical ways to design sessions and apply this approach in the classroom. However, just how the theory may be best used depends, to a greater or lesser extent, on the features of the program, as well as other external factors mediated by the context or settings in which the implementation is 
carried out. Nevertheless, designing CLIL sessions in accordance with the theoretical issues discussed here should help educators develop planning tools based on the application of the 4Cs framework, the integration of content and language through the language triptych, the development of students' thinking skills with a correct progression, and the design of appropriate activities based on the CLIL Matrix to get a balance between cognition and language.

\section{PROJECT WORK}

\section{Theoretical principles of project work}

Project work is an overall approach to language learning in which projects are central to the learning process (Thomas, 2000). The learning process is seen as a set of communicative tasks that are directly linked to curricular objectives and aims (Oura, 2001). The Project-Based Learning approach (PBL) is a method in which learning is organized around projects which, according to Thomas (2000), are complex tasks based on challenging questions or problems that involve learners in design, problem-solving, decision making, or investigative activities. These give students the opportunity to work relatively autonomously over extended periods of time, and they culminate in realistic products or cooperative presentations by groups (Istanto, 2013; Jones, Rasmussen, \& Moffitt, 1997; Thomas, Mergendoller, \& Michaelson, 1999).

Project work is also based on constructivism; thus, it shares with CLI some theoretical principles, such as the use of scaffolding, the necessity to provide comprehensible input and output, or the importance of significant learning. In addition, project work promotes specific types of learning, which can be considered the theoretical principles that underlie this approach.

Firstly, participant-directed learning processes focus on providing students opportunities to determine their own solutions using a teacher-suggested task as a starting point (De Graaf \& Kolmos, 2003). For example, teachers could suggest to students that their city needs to update the information about the most relevant destinations; stu- 
dents would then have to decide on the most appropriate method to solve this problem.

Secondly, project work requires research, decision-making, and production - these leading to deeper learning (De Graaf \& Kolmos, 2003). Using the previous example on updating information about local tourist destinations, students would have to identify appropriate media for delivering the information (for example, pamphlets, a tourist guide, or a blog) and present the advantages and disadvantages of each.

Thirdly, the use of inter-disciplinary learning connects the objectives within the curriculum to real-life situations and contexts, providing benefits and outcomes for each (De Graaf\& Kolmos, 2003). To continue the example of updating tourist information, teachers would need to relate their curricular objectives (that is, updated information on local tourist destinations) to real-life situations (for example, people who work in a tourist information centre who have to provide relevant information to tourists).

The last principle, but not least, is the achievement of groupbased learning, which is important, given that the majority of the learning processes described here take place in teams, and students have to develop group cooperation at all stages (Kolmos, 1999). In this sense, projects should be developed through cooperative working, giving students the opportunity to decide in groups the best options for each project so as to obtain successful solutions and outcomes. This strategy promotes communication among the group members

The theoretical principles of project work discussed in this section provide base upon which project work can be carried out through interactive practices that promote communication in real life situations. Furthermore, these theoretical principles are shared with CLIL, for which reason the implementation to a greater or lesser extent of the theoretical principles for project work depend, just as in the case of CLIL, amongst other aspects on the characteristics of the project and the context where the task is carried out (as well as the role 
of teachers, type of input and output, role of foreign language, and the allocation of time and subject).

\section{Theoretical issues in the application of project work}

The implementation of project work has been widely discussed, due to its practical nature and use. This section introduces some guidelines for the application of project work in the classroom. Coffey (2008) reviewed guidelines for creating effective PBL units:

- Start your unit with the end in mind; plan your unit for this purpose.

- $\quad$ Select and examine a central question; drive your unit through it.

- Define outcomes and criteria in order to assess your project; plan how to evaluate the outcomes.

- $\quad$ Map the project; determine the structure of the project.

- Manage the process, select strategies to support your project effectively.

These previous stages can be the starting point for project work. Teachers need to plan the project from the beginning (final outcome, assessment, structure, tool, strategies, roles), while learners need to know the plan from the beginning in order to organize their work. In addition, Blumenfeld et al. (1991) point out that there are two essential elements in project work that are developed by students guided by teachers: the identification of a question or problem to organize and drive activities, and the final outcome of these activities that results in a product that concludes the task.

In this interactive environment, students' freedom plays an important role in the implementation of project work because learners generate products that develop their knowledge through learning and doing (Kubon, Lopatkova, \& Mirovsky, 2013). In this context, students need to share and criticize opinions on their products that are concrete and explicit (for example, a videotape, a report, an article, a guide). Therefore, these interactions offer students more feedback and, consequently, they can extend their knowledge and revise their products. Finally, project work can also be considered a bridge between 
classroom situations and real-life experiences because students learn how to seek solutions when they face real problems.

Next, the role of teachers and students in project work should be introduced, following Coffey (2008). According to this author, the role of teachers consists of supporting students by providing appropriate guidance and feedback. In this sense, teachers must explain the different tasks, detail guidelines of the project, circulate within the classroom to respond to possible questions, and motivate students. Therefore, planning and flexibility are key factors for success in project work, and teachers are responsible for this. Furthermore, teachers must assess project work through objective tests, checklists, and/or rubrics, despite the fact that some teachers often only measure the final task or product. On the other hand, the role of students in project work is based on their organization and work in collaborative groups. They must do research using different sources, find information, and conduct their project in order to complete the final task or product. Thus, students are self-managers in their learning process, focusing on clear and realistic active roles.

The roles of both students and teachers are different from those in traditional methods. Traditional roles of teachers and students promote teacher-centred learning and the passive participation of students in the classroom; in project work, these are replaced by students' active involvement and learner-centred learning, while the role of teachers becomes that of facilitators. In addition, project work involves asking and refining questions, debating ideas, making predictions, designing plans and/or experiments, collecting and analysing data, drawing conclusions, communicating ideas and findings to others, asking new questions, and creating artefacts (Blumenfeld et al., 1991).

These actions involve real language use; thus, project work requires meticulous planning in order to fulfil the objectives established in each task. In this sense, project work must consider some a number of issues to achieve success in their planning (Eaude, 2013): 
- $\quad$ Significant Content: Teaching knowledge and developing skills related to the academic subject.

- $21^{\text {st }}$-century Competences: Problem solving, critical thinking, collaboration, communication, and creativity/innovation.

- In-Depth Inquiries: A rigorous and lengthened process of asking questions, using resources, and formulating answers.

- Driving Questions: Open-ended questions to capture students' tasks and frame their exploration.

- Need to Know: Knowledge as a need in order to answer the D ing Question and develop the final product.

- Voice and Choice: Students can make choices about the development and organization of their products

- Critique and Revision: Opportunities to share feedback with teacher and classmates about the quality of the work.

- Public Audience: Learners expound and explain their products to classmates and teacher.

As has been shown, these elements help teachers to frame PBL so as to implement it in the classroom. In addition to these, Nunan (1991) also claims that a project should consider the following issues in relation to language learning:

- Learning to communicate through the interaction, using the target language as medium of communication.

- Use of authentic texts as teaching materials in the learning context.

- Learners need opportunities to focus on both the language and the learning process.

- Focusing on students' experiences.

- The language learned in the classroom should be linked to the language used outside the classroom.

As can be observed, project work needs a specific environment or atmosphere with the appropriate characteristics to obtain positive results and successful projects. In this sense, it is necessary to point out that projects or tasks must be carefully planned; they introduce particular meanings that involve students in a process of manipulating, 
interacting, and producing - and, in the case that one of the aims of the task is to teach a foreign language (as occurs in CLIL), that target language can be integrated into these processes.

\section{CONCLUSION}

This article provides a bibliographical review on the implementation of project work in CLIL contexts. As has been discussed, present society needs changes to how foreign language learning is handled by its educational systems. Bilingual education has been considered as a possible solution to present social demands, offering multiple and diverse foreign language learning and usage practices. In this sense, project work is a tool that can be considered to fulfil the objectives and principles of CLIL through significant cooperative work. Project work integrates language and content learning by means of interaction and learning at the same time, leading students towards motivation, involvement, and efforts in a real life context.

The combination of CLIL and project work emphasizes the use of the target language as a medium of instruction during the development of the content subject, this being one of the main principles of CLIL. Project work in CLIL also promotes the learning of content in an interactive way, increasing students' opportunities for participation. In this context, it seems necessary that educators act as active facilitators so as to provide appropriate guidelines and support for the development of projects. As has been commented, the review of this methodological proposal focuses on current social and educational needs; and, for that reason, I suggest that each implementation of project work in CLIL be tailor made, thereby fulfilling any particular need or demand.

It seems that project work could be implemented very viably through CLIL. The availability of different published and electronic materials as well as previous experiences regarding project work in CLIL suggests that teachers and students could carry out their 
roles successfully without undue limitations, including objectives established in educational policy for curricular and program design, including teaching aims and learning outcomes. Furthermore, the integration of CLIL and project work can be driven successfully if the organization of such a project is based on the CLIL principles of content, communication, cognition, and culture.

As a final consideration for this review, project work can serve as a motivational instrument for bilingual teachers and students due to its practical and integrative nature. The integration of CLIL and project work can provide students with the opportunity to practice language for learning content through real life challenges (projects). This approach could increase the time available for language practice and promotes autonomous learning; consequently, the implementation of CLIL-based project work into the classroom should be a useful tool in the field of bilingual education. Project work in CLIL offers flexibility and can be adapted to any content subject, further supporting the argument that this approach can helplearners enhance their language skills and contribute to promoting multilingualism around the world.

\section{REFERENCES}

Anderson, L. W., Krathwohl,D. R., Airasian, P. W., Cruikshank, K. A., Mayer, R.E., Pintrich, P., ... Wittrock, M. (2001). A taxonomy forlearning, teaching, and assessing: A revision of Bloom's taxonomy of educational objectives. Boston, MA: Allyn \& Bacon.

Applebee, A. N. (1986). Problem in process approaches: Toward a reconceptualization of process instruction. In A. R. Petrosky \& D. Bartholomae (Eds.), The teaching of writing (pp. 95-113). Chicago, IL: National Society for the Study of Education.

Ausubel, D. (1978). In defense of advance organizers: A reply to the critics. Review of Educational Research, 48, 251-257.

Banegas, D. (2013). The integration of content and language as a driving force in the efl lesson. In E. Ushioda (Ed.), International 
perspectives on motivation: Language learning and professional challenges (pp. 82-97). New York, NY: Palgrave Macmillan.

Bauersfeld, H. (1995). The structuring of the structures: Development and function of mathematizing as a social practice. In L. P. Steffe \& J. Gale (Eds.), Constructivism in education (pp. 137-158). Hillsdale, NJ: Erlbaum.

Bloom, B. S., Engelhart, M. D., Furst, E. J., Hill, W. H. \& Krathwohl, D. R. (1956). Taxonomy of educational objectives: The classification of educational goals, Handbook I: Cognitive domain. New York, NY: Longmans, Green.

Blumenfeld, P. C., Soloway, E., Marx, R. W., Krajcik, J. S., Guzdial, M. \& Palincsar, A. (1991). Motivating project-based learning: Sustaining the doing, supporting the learning. Educational Psychologist, 26, 369-398.

Brumfit, C. (2001). Individual freedom in language teaching. Oxford, UK: Oxford University Press.

Bruner, J. S. (1978). The role of dialogue in language acquisition. In A. Sinclair, R. J. Jarvelle, \& W.J.M. Levelt (Eds.), The child's concept of language (pp. 241-256). New York, NY: Springer.

Byrd, D. (2014). Learning to teach culture in the L2 methods course. Electronic Journal of Foreign Language Teaching, 11, 76-89.

Byrne, D. (1984). Teaching writing skills. London, UK: Longman.

Cano, W. (2014). Manual CLIL para centros bilingües. La Rioja, Spain: Universidad Internacional de La Rioja.

Chamot, A. U. \& O’Malley, J. M. (1994). The CALLA handbook: Implementing the Cognitive Academic Language Learning Approach. Reading, MA: Addison Wesley.

Coffey, H. (2008). Project-based learning. Learn NC. Chapel Hill, NC: University of North Carolina School of Education. Retrieved from http://www.learnnc.org/lp/pages/4753

Coyle, D. (2005). CLIL: Planning tools for teachers. Nottingham, UK:

University of Nottingham, School of Education. 
Coyle, D. (2007). Content and language integrated learning: Towards a connected research agenda for CLIL pedagogies. International Journal of Bilingual Education and Bilingualism, 10(5), 543-562. http://dx.doi.org/10.2167/beb459.0

Coyle, D. (2009). Promoting cultural diversity through intercultural understanding: A case study of CLIL teacher professional development at in-service and pre-service levels. In M. L. CarrióPastor (Ed.), Content and language integrated learning: Cultural diversity (pp. 107-126). Berlin, Germany: Lang.

Coyle, D., Hood, P., \& Marsh, D. (2010). CLIL: Content and language integrated learning. Cambridge, UK: Cambridge University Press.

Cummins, J. (1984). Bilingualism and special education. Issues in assessment and pedagogy. Clevedon, UK: Multilingual Matters.

Cummins, J. (2000). Language, power, and pedagogy: Bilingual children in the crossfire. Clevedon, UK: Multilingual Matters.

Cummins, J. (2005). Using IT to create a Zone of Proximal Development for academic language learning: A critical perspective on trends and possibilities. In C. Davison (Ed.), Information Technology and Innovation in Language Education (pp. 105-126). Hong Kong: Hong Kong University.

Curtain, H. (1991). Methods in elementary school foreign language teaching. Foreign Language Annals, 24, 323-329.

De Graaf, E., \& Kolmos, A. (2003). Characteristics of problem-based learning. International Journal of Engineering Education, 19, 657-662.

Eaude, T. (2013). Primary education: A literature review. The Hague, the Netherlands: International Baccalaureate.

Eurydice. (2006). Content and language integrated learning (CLIL) at school in Europe. Brussels, Belgium: Eurydice European Unit. Retrieved from http://www.indire.it/lucabas/lkmw_file/ eurydice/CLIL_EN.pdf

European Commission (2012). Europeans and their language: Special Eurobaromenter 386. Retrieved from the European Commission 
website: http://ec.europa.eu/public_opinion/archives/ebs/ ebs_386_en.pdf

Fried-Booth, D. L. (1986). Project work. Oxford, UK: Oxford University Press.

Hall, S. (1980). Encoding/decoding. In Centre for Contemporary Cultural Studies (Ed.), Culture, media, language: Working papers in cultural studies (pp. 128-38). London, UK: Hutchinson.

Istanto, J. W. (2013). Implementing project-based approach to nurture learners' cultural awareness at the beginner level. Electronic Journal of Foreign Language Teaching, 10, 276-291.

Jones, B. F., Rasmussen, C. M., \& Moffitt, M. C. (1997). Real-life problem solving: A collaborative approach to interdisciplinary learning. Washington, DC: American Psychological Association. Juárez, M. M. (2013). Teaching and learning science in context. Revista de Lenguas para Fines Especificos, 19, 183-208.

Kramsch, C. (2014). The challenge of globalization for the teaching of foreign languages and cultures. Electronic Journal of Foreign Language Teaching, 11, 249-254.

Krashen, S. D. (1985). The input hypothesis: Issues and implications. New York, NY: Longman

Kolmos, A. (1999). Progression of collaborative skills. In J. Conway \& A. Williams (Eds.), Themes and variations in PBL: Refereed proceedings of the 1999 Bi-ennial PBL, Conference, July 7-10, 1999, Montreal, Canada. Sydney, Australia: Australian Problem Based Learning Network.

Kubon, V., Lopatkova, M. \& Mirovsky, J. (2013). A case study of a free word order. Proceedings of the 27th Pacific Asia Conference on Language, Information and Computation (pp. 222-231), Taipei, Taiwan: Department of English, National Chengchi University. Llinares, A., Morton, T. \& Whittaker, R. (2012). The roles of language in CLIL. Cambridge, UK: Cambridge University Press. 
Long, M. H. (1983). Native speaker/non-native speaker conversation and the negotiation of comprehensible input. Applied Linguistics, 4, 126-141

Long, M. H. (1996). The role of the linguistic environment in second language acquisition. In Ritchie, W. C., \& Bahtia, T. K. (Eds.), Handbook of second language acquisition (pp. 413-68). New York, NY: Academic Press.

Mehisto, P., Marsh, D. \& Frigols-Martín, M. J. (2008). Uncovering CLIL: Content and language integrated learning in bilingual and multilingual education. Oxford, UK: Macmillan Education.

Muñoz, C. (2007). CLIL: Some thoughts on its psycholinguistic principles. Revista Española de Lingüística Aplicada, 1(Extra 1), 17-26.

Nunan, D. (1991). Communicative tasks and the language curriculum. TESOL Quarterly, 25, 279-295.

Oura, G. K. (2001). Authentic task-based materials: Bringing the real world into the classroom. Sophia Junior College Faculty Bulletin, 21, 65-84.

Peirce, C. S. (1960-1966). Collected papers of Charles Sanders Peirce. Cambridge, MA: Belknap Press of Harvard University Press.

Pérez Gracia, E.(2014). Multicultural education for language teacher education and CLIL. In Pixel (Ed.), Conference proceedings: ICT for language learning (pp. 42-45). Limena, Italy: Libreria Universitaria.it Edizioni.

Pérez Vidal, C. (1997). Language teacher training and bilingual education in Spain. In P. Van de Craen \& D. Wolff (Eds.), Language teacher training and bilingual education technical report: Thematic network project n. 9: Evaluation conference (pp. ). Lille, France: University of Lille III.

Pérez Cañado, M. L. (2012). CLIL research in Europe: Past, present, and future. International Journal of Bilingual Education and Bilingualism, 15, 315-341. 
Prince, M. (2004). Does active learning work? A review of the research. Journal of Engineering Education, 93(3), 223-231. http://dx.doi. org/10.1002/j.2168-9830.2004.tb00809.x

Richards,J.C.\&Rodgers, T.S. (2001).Approachesandmethodsinlanguage teaching (2nd ed.). Cambridge, UK: Cambridge University Press. http://dx.doi.org/10.1017/CBO9780511667305

Saussure, F. (1922). Cours de linguistique générale (2nd ed.). Paris, France: Payot.

Searle, J. R. (2002). Consciousness and language. Cambridge, UK: Cambridge University Press.

Sierra, J. M. (2011). CLIL and project Work: Contributions from the classroom: Content and language integrated learning. In Y. Ruiz de Zarobe, J. M. Sierra, \& F. Gallardo del Puerto (Eds.), Contributions to multilingualism in European contexts (pp. 211239). Berlin, Germany: Lang.

Swain, M. (1985). Communicative competence: Some roles of comprehensible input and comprehensible output in its development. In S. Gassand \& C. Madden (Eds.), Input in second language acquisition (pp.235-253). Rowley, MA: Newbury House.

Sylvén, L. K. (2013). CLIL in Sweden - Why does it not work? A metaperspective on CLIL across contexts in Europe. International Journal of Bilingual Education and Bilingualism, 16, 301-320. http://dx.doi.org/10.1080/13670050.2013.777387

Thomas, J. W. (2000). A review of research on project-based learning. San Rafael, CA: Autodesk Foundation. Retrieved from http://www. bobpearlman.org/BestPractices/PBL_Research.pdf

Thomas, J. W., Mergendoller, J. R. \& Michaelson, A. (1999). Projectbased learning: A handbook for middle and high school teachers. Novato, CA: Buck Institute for Education.

Towomey, C. (2005). Constructivism: Theory, perspectives, and practice. New York, NY: Teachers College Press. 
Vygotsky, L. S. (1978). Mind in society: The development of higher psychological processes. Cambridge, MA: Harvard University Press.

Wren-Lewis, J. (1983). The encoding/decoding model: Criticisms and redevelopments for research on decoding. Media Culture and Society, 5, 179-97. 